\title{
JUDICIAL REVIEW OF AGENCY ACTION: THE PROBLEMS OF COMMITMENT, NON-CONTRACTBILITY, AND THE PROPER INCENTIVES
}

\author{
NICHOLAS S. ZEPPOS $\dagger$
}

As befits any important case, Chevron ${ }^{1}$ has produced what might be considered several generations of commentary. In the first, commentators debated the importance of Chevron for the balance of power in the admimistrative state. In this context, some viewed the decision as a troubling shift of power away from the judiciary to the President. ${ }^{2}$ Others turned their attention to explaining why the Court announced the so-called Chevron doctrine. The puzzle here was to explain the apparently selfless act of the Court giving up its own power to overturn agency decisions. ${ }^{3}$ Finally, when both the ramifications of and reasons for Chevron began to be understood, academic commentators began speculating whether the decision was still viable or whether it had proven to have had hittle impact in the field of admimistrative law. ${ }^{4}$

It is against this dense background that Professors Shapiro and Levy address Chevron and related problems of scope of review. ${ }^{5}$ Despite the already extensive treatment of Chevron, they

$\dagger$ Professor of Law, Vanderbilt University. I am grateful to Jason Johnston and Bob Rasmussen for helpful comments.

1. Chevron, U.S.A., Inc. v. Natural Resources Defense Council, Inc., 467 U.S. 837 (1984).

2. See William N. Eskridge, Jr. \& John Ferejohn, Playing the Article I, Section 7 Game, 80 GEO. L.J. 523 (1992); Cynthia R. Farina, Statutory Interpretation and the Balance of Power in the Administrative State, 89 CoLUM. L. REV. 452 (1989); Richard J. Pierce, Jr., Chevron and Its Aftermath: Judicial Review of Agency Interpretations of Statutory Provisions, 41 VAND. L. REv. 301 (1988); Cass R. Sunstein, Law and Administration After Chevron, 90 Colum. L. REv. 2071 (1990).

3. See Linda R. Cohen \& Matthew L. Spitzer, Solving the Chevron Puzzle, 57 LAW \& ConTEMP. ProBs., Spring 1994, at 65; Peter L. Strauss, One Hundred Fifty Cases Per Year: Some Implications of the Supreme Court's Limited Resources for Judicial Review of Agency Action, 87 Colum. L. REV. 1093 (1987).

4. See Cohen \& Spitzer, supra note 3; Thomas W. Merrill, Judicial Deference to Executive Precedent, 101 YALE L.J. 969 (1992); Peter H. Schuck \& E. Donald Elliott, To the Chevron Station: An Empirical Study of Federal Administrative Law, 1990 DUKE L.J. 984.

5. Sidney A. Shapiro \& Richard E. Levy, Judicial Incentives and Indeterminacy in 
manage to add significantly to the understanding and discussion of scope of review. Indeed, they go well beyond that to offer more general msights and understandings about the behavior of the judicial branch. Drawimg on the rational choice hiterature, Shapiro and Levy develop a model that identifies the interests that judges seek to maximize and how those interests are implicated in the field of adıninistrative law. ${ }^{6}$ They then describe the ways in which Chevron and its aftermath are related to the judiciary's efforts to maximize its ideological imterests. Ultimately criticizing what they perceive as the demise of Chevron, they prescribe an ambitious agenda for reforming not only the problein to which Chevron was addressed-review of agency interpretation of a statute-but the whole area of scope of review. ${ }^{7}$ It is an anbitious and creative project imdeed, and in doing so, Shapiro and Levy have advanced the debate substantially.

My misgivings about their project stem almost entirely froin three central points. First, I believe that Sliapiro and Levy move too quickly im asserting the determinacy of the Chevron two-step. As I argue below, a belief in the determinacy of that test must arise primarily from the more general institutional realigninent identified with Chevron and not particularly from the test itself. The move away from Chevron is explained by Shapiro and Levy as a judicial effort to maximize ideological returns by shaping indeterminate doctrine to replace the two-step test. I argue that the dissembling of Chevron involved a more coinplex process in which the mability of the Justices to secure and observe true commitments to the Chevron framework ex post doomed the Court's project. This, in turn, is related to my second objection. Shapiro and Levy seem to argue that determinacy of doctrine and deference are directly related. In fact, however, the relationship they posit is not inevitable. Indeed, the current Supreme Court is developing what it believes to be a highly determinate doctrine of statutory interpretation that gives little deference to administrative agencies. In this respect, Shapiro and Levy fail to see that judges will seek to develop determinate doctrimes that-unlike Chevron-call for highly developed judicial craft skills. When this occurs, determinate doctrime will be used to curb agency action.

Substantive Review of Administrative Decisions, 44 DUKE L.J. 1049 (1995).

6. Id. at $1053-45,1060-62$.

7. Id. at 1071-74. 
Finally, although usefully broadening our understanding of Chevron to include judicial incentives, Shapiro and Levy ignore other incentives and institutional arrangements. Chevron can be understood as affecting not only judicial incentives, but also significantly altering the incentives for agencies. This change in the incentive structure inay have proven to be undesirable for the differing proponents of deference to agencies-both those who believe that agencies are due deference because of their reasoned exercise of expert judgment and those who believe that agencies are inore pohtically accountable. Against this background, the post-Chevron law that Shapiro and Levy seein to lament is in fact more stable and better designed to serve the goals they articulate for themselves than the legislative ainendinents they offer.

\section{The Chevron Contract and the Problems of COMMITMENT, OBSERVATION, AND VERIFICATION}

Shapiro and Levy start their paper with a central but controversial proposition. They argue that Chevron put in place a new and more determinate standard for judicial review of agency interpretations of statutory law. This inore determinate craft norin limited judges in their efforts to maximize their ideological interests on questions of agency policy. I say "controversial" because it is not readily apparent that the Chevron two-step itself is determinate. The Court stated that if Congress had addressed the issue, the agency interpretation was irrelevant because the will of the legislature is supreme. ${ }^{9}$ Earlier cases had set forth a similar formulation for review of agency action. ${ }^{10}$ Left unresolved by Chevron were a number of important issues: How much ambiguity was required before the case became a Chevron step-two case? What materials were legitmuately included annong the traditional tools of statutory construction to be used at step one? More specifically and fundainentally, at the time Chevron was decided there was no stable foundational doctrine of statutory interpretation to which the Court could easily refer for resolution of step-one cases. In-

8. Id. at 1069.

9. Chevron, U.S.A., Inc. v. Natural Resources Defense Council, Inc., 467 U.S. 837, 842-43 (1984).

10. See Federal Election Comm'n v. Democratic Senatorial Campaign Comm., 454 U.S. $27,31-32$ (1981); SEC v. Sloan, 436 U.S. 103, 118 (1978); NLRB v. Brown, 380 U.S. 278,291 (1965). 
deed, it is no accident that the instability of Chevron coincided with an enormous outburst of scholarly literature debating theories of statutory interpretation. ${ }^{11}$ Moreover, the textuahst revival was being advanced in the lower courts by then-Judge Scalia. ${ }^{12}$ And certainly witl his arrival at the Supreme Court, the entire Chevron step-one landscape became a inajor intellectual battlefield over theories of statutory interpretation.

So the promise of determinacy and the stability of Chevron were never really serious possibilities given the intellectual and political climate in which the case was to be applied. If there was any possibility that Chevron could inake the law more determinate, that may liave had less to do with the two-part test than with the attitude or nood reflected in the general rlietoric of the opinion. ${ }^{13}$ The Court cautioned that judges are not elected and liave no political constituencies. ${ }^{14}$ On the other hand, adininistrative agencies are controlled by the President, who is directly accountable to the people. In other words, Chevron's potential for certainty or determinacy was not in the two-part test, but in its operation as a kind of super-strong default rule. Unless the party challenging agency action could show a contrary intent by the inost coinpelling evidence, the agency's interpretation of the statute had to be upleeld. Like the other canons being developed by the Court, ${ }^{15}$ the Chevron case shifted the burden to the challeng-

11. See, e.g., T. Alexander Aleinikoff, Updating Statutory Interpretation, 87 MiCH. L. REV. 20 (1988); Frank H. Easterbrook, Statutes' Domains, 50 U. CHI. L. REV. 533 (1983); William N. Eskridge, Jr., Dynamic Statutory Interpretation, 135 U. PA. L. REv. 1479 (1987); William N. Eskridge, Jr. \& Philip P. Frickey, Statutory Interpretation as Practical Reasoning, 42 STAN. L. REV. 321 (1990); Daniel A. Farber, Statutory Interpretation and Legislative Supremacy, 78 GEO. L.J. 281 (1989); Jonathan R. Macey, Promoting Public-Regarding Legislation Through Statutory Interpretation: An Interest Group Model, 86 Colum. L. REv. 223 (1986); Richard A. Posner, Statutory Interpretation-In the Classroom and in the Courtroom, 50 U. CHI. L. REv. 800 (1983); Edward L. Rubin, Law and Legislation in the Administrative State, 89 COLUM. L. REV. 369 (1989).

12. See FAIC Sec., Inc. v. United States, 768 F.2d 352, 361-64 (D.C. Cir. 1985); Hirschey v. Federal Energy Regulatory Comm'n, 777 F.2d 1, 7-8 (D.C. Cir. 1985) (Scalia, J., concurring).

13. It is not unusual to have the Court send signals about scope of review to the lower courts in the form of mood and atmosphere. See Universal Camera Corp. v. NLRB, 340 U.S. 474, 487-91 (1951).

14. Chevron, U.S.A., Inc. v. Natural Resources Defense Council, Inc., 467 U.S. 837, 865 (1984).

15. See William N. Eskridge, Jr. \& Philip P. Frickey, Quasi-Constitutional Law: Clear Statement Rules as Constitutional Lawmaking, 45 VAND. L. REV. 593, $611-29$ (1992); Cass R. Sunstein, Interpreting Statutes in the Regulatory State, 103 HARV. L. REV. 405, 454-60 
er to show by a clear statement that the agency's decision was contrary to legislative intent. ${ }^{16}$

Thus, the commitment to certainty that Shapiro and Levy find in Chevron probably did not come from the adopted two-part test. Rather, the strong deference signals can be found in the more general discussion and rhetoric of the opinion. The distinction is significant for two reasons. First, it is relevant to whether reforms that rewrite the standards of review to restate the Chevron test will be worthwhile or successful. Second, it may offer another explanation for why Chevron was so quickly eroded by the Court.

On Shapiro and Levy's account, we are still nonetheless left to wonder why all of the participating Justices joined in the Chevron opinion. In fact, the puzzle becoines even more striking in light of Shapiro and Levy's account of what judges choose to maximize. They posit that judges like to achieve their ideological outcomes and that this impulse is particularly strong in administrative law cases. Curbing the desire for ideological utility is the craft norm that limits judicial discretion by putting the judge's reputation at stake for gross departures from doctrine. Thus, judges should adopt vague craft norms to maximize ideological utility. If this is so, then why was Chevron decided or written as it was in the first place? On Shapiro and Levy's account, the Chevron twostep severely constrained judges yet it was unanimously adopted contrary to their ideological self-interest.

As Shapiro and Levy note, others have offered hypotheses for why the Court abdicated its own power in Chevron. Most of the arguments advanced are institutional in character. Peter Strauss argues that Chevron was a response to the Court's docket problems. ${ }^{17}$ He suggests that the Court in Chevron opted for the national uniformity secured by the affirmance of the agency's views because of the Court's limited ability to correct the errors that could occur in the lower courts and could severely disrupt national, uniform programs if they were not reviewed. ${ }^{18}$ Linda Cohen and Matt Spitzer argue that Chevron was a necessary correction by a conservative Supreme Court to signal to the more hiberal

(1989).

16. See Chevron, 467 U.S. at 860-62.

17. See Strauss, supra note 3 , at 1117-22.

18. Id. at 1121 . 
appellate court judges that the actions of the Republican agencies should be given great deference. ${ }^{19}$

Shapiro and Levy do not dispute either of these explanations and indeed seen to agree or assume that for the Court in 1984 Chevron represented a clear policy choice in favor of more deference and possibly an atypical judicial abdication of the power to maximize ideological utility. Unless we explain Chevron as a sinply overwritten and overstated blunder by the Court, it is hard to offer a nonstrategic reason for the opinion. Many commentators and lower court judges read the opinion as an inportant shift in doctrine and as the definitive statement on deference. ${ }^{20}$ Thus, it seems sensible to credit soine of the nustitutional arguments advanced in support of Chevron. Also, consistent with Shapiro and Levy's rational-choice focus, we can assume that in giving up ideological utility the Court believed that it was getting some other benefit: more leisure time, fewer agency costs in administering the courts of appeals, or an increase in the craft quality of other cases as a result of a higlter docket.

Chevron then can be understood as a kind of contractual commitınent by the Justices to forego ideological utility for other goals. In this respect, all of the Justices are better off because they all get the benefit of the Chevron rule. And because all of thein adliere to the rule, there is no danger of opportunistic behavior by a Justice to defect: the majority of adherents to Chevron can outvote any Justice seeking to return to maximizing ideological utility. This last point is essential to the stability of the Chevron contract. If all of the Justices cooperate, they are all better off. But if some of thein forge a inajority and clieat, then they will be inaximizing the ideological utility that their colleagues have foregone, pronipting others to defect as well. The chances of cooperation are enlianced when the Justices play the Chevron game repeatedly. The liberal Justices know that if they defect and fail to defer under Chevron, the conservative Justices will retaliate in kind, which keeps the Justices cooperating.

Therefore, essential to the inanitenance of the Chevron rule is the ability of the Justices to cooperate in complying with that

19. See Cohen \& Spitzer, supra note 3, at 68.

20. See sources cited supra note 2; Kenneth W. Starr, Judicial Revicw in the PostChevron Era, 3 Yale J. REg. 283, 306-07 (1986); INS v. Cardoza-Fonseca, 480 U.S. 421, 453 (1987) (Scalia, J., concurring). 
agreement and to discover and retaliate for any breaches that might occur. Although the repeat plays give the Justices ample opportunity to monitor each other, the problem is that the amorphousness of the Chevron test makes accurate ex post momitoring by the Justices almost impossible to undertake. Chevron seemed to say "defer unless Congress's imtent is clear." With this vague contract, there are severe problems im auditing and monitoring comphance. The Justices must be able to observe the behavior of their colleagues. The Justices must also be able to verify breaches of the agreement. I would suggest that these problems-particularly those of verification-are so acute as to make the Chevron contract an impossible one to enter. ${ }^{21}$

All of the Justices post-Chevron have had ample opportumity to observe the actions of each other. In the most public of judicial actions, the Justices' votes to uphold or reject agency decisions reveal their respective views on Chevron. Along with voting, the Justices must also write opimions justifying results. When an agency decision is overturned, the opmion must explain whether or not the Chevron framework is being followed. In their private discussions and deliberations as well, the Justices also observe each other's behavior and commitment to Chevron.22

Despite these opportunities to observe Chevron compliance or behavior, the Justices lacked any mechanism for accurately verifying whether in fact all were following the Chevron bargain. ${ }^{23}$ In the first major post-Chevron case, INS v. Cardoza-Fonseca, ${ }^{24}$ the liberal Justices seemed to breach the Chevron deal and did not defer. Using traditional tools of statutory interpretation, the major-

21. For application and development of these concepts in contract law, see Alan Schwartz, Relational Contracts in the Courts: An Analysis of Incomplete Agreements and Judicial Strategies, 21 J. LEGAL STUD. 271, 279-80 (1992). See generally Ronald J. Gilson \& Robert H. Mnookin, Disputing Through Agents: Cooperation and Conflict Between Lawyers in Litigation, 94 COLUM. L. REV. 509 (1994) (describing difficulty of monitoring cooperative behavior between opposing counsel). The general concepts are explained in David M. Kreps, Corporate Culture and Economic Theory, in PERSPECTIVES ON POSITIVE Political ECONOMY 90 (James E. Alt \& Kenneth A. Shepsle eds., 1990).

22. See Bernard Schwartz, "Shooting the Piano Player"? Justice Scalia and Administrative Law, 47 ADMIN. L. REV. 1, 46-48 (1995) (reviewing internal deliberations reflected in transmittals between Justices Scalia and Stevens on whether the majority opinion in Cardoza-Fonseca was consistent with Chevron).

23. Here the problems of observability and verifiability overlap since the Justices could not actually observe each other's state of mind through votes and opinions.

24. 480 U.S. 421 (1987). 
ity concluded that the intent of Congress was clear and contrary to the agency's construction. ${ }^{25}$ This rhetoric of the inajority opinion-written by Justice Stevens, the author of Chevron-directly rejected any claim that Cardoza-Fonseca was a departure from Chevron. ${ }^{26}$ Despite this effort to claim fidelity to Chevron, the more conservative dissenters would view the majority liberals as defecting from the Chevron commitment. When three Justices dissent and invoke the deference.principle of Chevron, they will find it difficult to take seriously the majority's assertion that the statute was so clear that no deference could be granted. ${ }^{27}$

The problein, therefore, was that even if the Justices' behavior was observable in inany ways, there remained no mechanism for accurately verifying whether a breach of the agreement occurred. Perhaps the solution to this verification problem was to be found in the ideological lineup of Justices in a case like CardozaFonseca. But that was not a viable solution because of two comphications. First, in a Court with three wings-liberal, conservative, and inoderate (or "crafters" to use the Shapiro and Levy language)-the ideological flanks may occasionally pick up votes from the inoderate or craft wing. When this occurs-particularly when the moderate or craft wing oscillates in results-the ideological breachers can claim fidelity to Chevron since the nonideological Justices were essential to a inajority. Second, when some of the Justices refuse to defer by casting what inight be considered contra-ideological votes, joining with their usual ideological opponents-i.e., conservative Justice joins hiberal Justices to invahidate conservative agency pohicy-the verification probleins becoine difficult. The odd coalition provides a plausible basis for the claim that there has actually been coinpliance with Chevron rather than deference because the agency loses at step one. Here, ironically, Justice Scalia-once a Chevron proponent-has proven to be instrumental in the unraveling of Chevron. ${ }^{28}$ His adoption of an

25. See id. at 446.

26. Id. at $446-48$.

27. This phenomenon is graphically illustrated by the cases in which the Court splits 5-4 with either the majority or a substantial minority insisting that no ambiguity exists to trigger Chevron step two. See Lampf v. Gilbertson, 501 U.S. 350, 362 (1991); NLRB v. Curtin Matheson Scientific, Inc., 494 U.S. 775, 796 (1990). Consider also the remarkable situation in Pauley v. BethEnergy Mines, Inc., 501 U.S. 680, 706 (1991), in which all seven of the Justices in the majority found the statute ambiguous and upheld the agency's views under Chevron step two. Justice Scalia insisted in a lone dissent that the statute was clear and required the agency to lose at step one of Chevron. Id.

28. See Thomas W. Merrill, Textualism and the Future of the Chevron Doctrine, 72 
interpretive theory that presumes textual determinacy has shifted him into an anti-deference position, sometimes casting "hiberal" votes to form odd coalitions to mvalidate agency decisions. ${ }^{29}$ Verifymg who the Chevron cheaters are has proven to be extremely difficult, even when most of the judicial behavior has been readily observed.

Against this background, the rational strategy for the dissenters in Cardoza-Fonseca should have been to defect from Chevron, hoping to persuade some of the moderate or craft Justices that the agency should lose at step one im the next liberal agency case. They cannot allow the hiberal Justices to follow Chevron selectively while they forego ideological utility for the good of the Court. Of course, after that the liberal Justices may choose to cooperate by again deferring and attempting to restore the Chevron equilibrium. The problem is that they may not have seen Cardoza-Fonseca as a defection, but as a sincere apphication of Chevron responding to a conservative defection with one of their own.

Thus, if we assume that Chevron was indeed designed as a shift and that the strong language of the opinion reflected a general commitment by the Justices for inore political control than judicial control, there simply was no easy way for the Justices to momitor and audit each other's behavior. What some Justices inight liave viewed as an agency reversal under an application of Chevron, another group might have perceived as a defection to maximize ideological utility. When the latter group retahates by not deferring and the former beheves that the retaliation was unwarranted, the result may be a return to the pre-Chevron uncertamty. The Chevron agreement was not only sliort-lived but doomed from the beginning.

The agreement and auditing problems outlined above might have been even more severe than initially suggested, particularly for the more liberal Justices. After Chevron, with a Republican

WASH. U. L.Q. 351, 366 (1994) (describing how Justice Scalia's commitment to textualism permits him to find a statute's "plain meaning" more frequently and thus requires less deference to agency interpretations).

29. See City of Chicago v. Environmental Defense Fund, 114 S. Ct. 1588, 1594 (1994); INS v. Cardoza-Fonseca, 480 U.S. 421, 423-54 (1987) (Scalia, J., concurring); see also Nicholas S. Zeppos, Chief Justice Rehnquist, the Two Faces of Ultra-Pluralism, and the Originalist Fallacy, 25 RUTGERS L.J. 679, 688-97 (1994) (arguing that Justice Scalia's quest for methodological consistency will lead him to cast votes contrary to his ideological preferences in the individual case). 
President, we would expect that the pohicies of the administrative agencies would be more conservative. For the conservative Justices, the Chevron commitment may be relatively costless. Rarely, if ever, will there be a case that reviews a liberal agency action. Thus, the conservative Justices can commit themselves to cooperate and play by the Chevron rules and still maximize their ideological utility. Under Chevron, mostly conservative agency actions will be upheld under the deference rule. The conservative justices can consistently pledge their commitment to Chevron without ever sacrificimg ideological utility. The danger for the liberal Justices is obvious. The heral Justices may legitimately fear that the conservative Justices will abandon Chevron when the White House shifts to the other party. Fearing this bait and switch tactic by the conservatives, the liberal Justices will rationally begin to defect almost immediately after Chevron. True to this prediction, the conservative Justices seemed to abruptly shift their views on Chevron without even awaiting the election of a Democratic President, aggressively reviewing some of the positions taken by agencies under President Bush. ${ }^{30}$

In sum, the ex post moritoring and auditing problems with the Chevron commitment are enornous. The Justices will not be able to separate out sincere agency reversals under Chevron from defections to maximize ideological utility. More fundamentally, with agency policies skewed on the political spectrum, the Justices who are truly sacrificing ideological utility in the early afterınath of Chevron will rationally fear conservative defections after a change in the White House. Knowing this, the rational strategy becomes almost immediate defection from Chevron.

\section{DETERMINATE CRAFT NORMS AND THE RELATIONSHIP TO JUDICIAL REVIEW}

Shapiro and Levy relate determinate craft norins to Chevron and the restoration of the primacy of political accountability as the dominant form of control on agency decisionmaking. ${ }^{31}$ But there

30. See Lechmere, Inc. v. NLRB, 502 U.S. 527, 539-41 (1992); Presley v. Etowah County Comm'n, 502 U.S. 491, 508-09 (1992); EEOC v. Arabian American Oil Co., 499 U.S. 244, 257 (1991), overruled by the Civil Rights Act of 1991, 42 U.S.C. § 2000 (Supp. IV 1994).

31. Shapiro \& Levy, supra note 5, at 1068 ("[M]ost cases would be resolved in favor of the agency ... under the determinate version of Chevron."). 
is no clear relationship between determinate craft norms and deference to agencies. In other words, it is possible to have what appear to be more determinate craft norms for judicial review but have power taken away from administrative agencies. This is most dramatically illustrated by the fiercely determinate textualism of Justice Scalia, but is increasingly apparent in the work of the entire Court. ${ }^{32}$ Three developments in particular demonstrate this point.

First, there is an almost fanatical movement in the Court to have dictionary definitions control the meaning of statutes. ${ }^{33}$ This trend now imcludes those cases in which the agency has interpreted a statute as well. The Court has not hesitated to invalidate an agency's action when the agency has read a statute in a way that is contradicted by a consensus of meaming found in the dictionaries. ${ }^{34}$ Unfortunately for agencies, the use of dictionaries is a oneway street. That is, even though an agency interpretation that confiicts with the consensus dictionary definition is presumed imvalid, evidence of conflicting dictionary definitions does not by itself make a statute ambiguous; this would make it a Chevron step-two case. ${ }^{35}$ The Court seems to beheve that it lias made doctrine more determinate by using dictionaries as a predictable source of meanimg. But the result has been to exert greater judicial control over admimistrative agencies.

Second, the Court lias imcreasingly used structural and limguistic canons of interpretation in ways that seem to make doctrine more determinate. Agaim, however, the effect has been to limit agency discretion. Two of the structural canons in particular illustrate the point. Consider first expressio unius est exclusio alterius-the expression of one item imphes exclusion of others. The typical case in the agency context is when Congress has authorized the agency to take action $X$ or regulate $X$, and the agency then proceeds to undertake $Y$ or regulate $Y$. There are two ways to understand the express reference to $X$ and the absence of reference to $\mathrm{Y}$ im the statute. It can be viewed as legislative inad-

32. See William N. Eskridge, Jr. \& Philip P. Frickey, The Supreme Court, 1993 Term, Foreword: Law as Equilibrium, 108 HARV. L. REV. 27, 73 (1994) (describing certainty of textualism and its effects on agencies).

33. See id. at 73-74; Note, Looking It Up: Dictionaries and Statutory Interpretation, 107 HARV. L. REV. 1437 (1994).

34. MCI Telecommunications Corp. v. AT\&T, 114 S. Ct. 2223, 2229 (1994).

35. See id. at 2229-30; Brown v. Gardner, 115 S. Ct. 552, 555 (1994). 
vertence or inattention, which suggests ambiguity; or it can be understood as a conscious legislative decision to draw the regulatory boundary at $\mathrm{X}$ and not to allow $\mathrm{Y}$. The former, of course, is a Chevron step-two case, while the latter would be resolved against the agency at step one. The expressio unius canon adopts the latter understanding of structure and therefore operates as a significant restraint upon the agency. The Supreme Court and the courts of appeals have now firmly committed theinselves to using this canon to constrain agency power. ${ }^{36}$

Of similar limiting effect is the canon noscitur a sociis-a word is known by the ineaning of surrounding words. The canon is typically invoked in a case in which the statute gives the agency a hist of powers to exercise. The question is whether the terms in the hist all share a common meaning or whether more general terms in the hist convey broader powers. The situation obviously poses a problein of statutory ambiguity, but the ambiguity is eliminated by use of the canon. The general power claimed by the agency is constrained by the common meaning-again the dictionary-given to the surrounding words.

These two canons were recently invoked by the D.C. Circuit in Sweet Home Chapter v. Babbitt ${ }^{37}$ and demonstrate the way in which they impose limits on agencies. The issue in Sweet Home Chapter was the legahty of the EPA's regulation that makes destruction of animal habitat a violation of the Endangered Species Act. ${ }^{38}$ The Act inakes it a crime for any person to "take" any endangered species. "Take" is defined to mean "harass, harm, pursue, hunt, shoot, wound, kill, trap, capture, collect, or to attempt to engage in any such conduct." ${ }^{\text {39 }}$ The D.C. Circuit held that the EPA's interpretation was contrary to the statute. ${ }^{40}$ Central to the court's analysis were the two structural canons. The court first noted that all of the terms in the definition "contem-

36. See City of Chicago v. Environmental Defense Fund, 114 S. Ct. 1588, 1591-92 (1994); Sweet Home Chapter v. Babbitt, 17 F.3d 1463, 1471-72 (D.C. Cir. 1994), cert. granted, 115 S. Ct. 714 (1995); Kelley v. EPA, 15 F.3d 1100, 1108 (D.C. Cir. 1994), cert. denied, 115 S. Ct. 900 (1995); Railway Labor Executives' Ass'n v. National Mediation Bd., 988 F.2d 133, 139 (D.C. Cir. 1993), aff'd on reh'g en banc, 29 F.3d 655, 666 (D.C. Cir. 1994), cert. denied, 63 U.S.L.W. 3686 (U.S. Mar. 21, 1995) (No. 94-890); Wachtel v. Office of Thrift Supervision, 982 F.2d 581, 586 (D.C. Cir. 1993).

37. 17 F.3d at 1465 .

38. Id. at 1464 .

39. 16 U.S.C. \& 1532(19) (1988).

40. Sweet Home Chapter, 17 F.3d at 1464-65. 
plate the perpetrator's direct application of force against the animal." 41 Invoking noscitur $a$ sociis, the court concluded that the word "liarm" could not be read to include liabitat modification, but rather, like all of the other terms, applied only to actions directed toward an endangered species itself. ${ }^{42}$ The court also relied upon the fact that other provisions of the Act expressly allowed the EPA to take actions for habitat preservation and tellingly allowed for purchase of private property to protect the rights of owners. For the court, these other express references to habitat protection implied that no such autliority was granted in the general prohibition section-expressio unius est exclusio alterius. ${ }^{43}$ Ambiguity is eliminated through the use of these structural canons with doctrine more determinate but agencies worse off.

Fimally, the Supreme Court has developed a set of substantive interpretive canons that constrain agency decisionmaking while making doctrime more determinate. Assume that a statute administered by an agency is ambiguous. Presuniably under Chevron, this case should be resolved under step two. But if the substantive canons are invoked to eliminate the ambiguity or shift the burden of proof to the agency to show that the power to act is explicitly authorized, the case now becomes a loss for the agency at step one of Chevron. There is an intersection liere between the Court's development of constitutional or quasi-constitutional norms ${ }^{44}$ outside of administrative law and the review of agency decisions that transgress these newly invigorated constitutional protections. Thus, Lechmere, Inc. $v . N L R B,{ }^{45}$ in which the Court invalidated the NLRB's imterpretation allowing union organizers access to the private property of the owner, is fully consistent with the Court's recent cases giving greater constitutional protection for property rights. ${ }^{46}$ Presley v. Etowah County Commission, ${ }^{47}$ in which the Court invalidated the Department of Justice's reading of the Voting Rights Act to cover changes in the internal structures of gov-

41. Id. at 1465 .

42. Id. at 1466 .

43. Id.

44. See generally Eskridge \& Frickey, supra note 15.

45. 502 U.S. 527, 539 (1992).

46. See Dolan v. City of Tigard, 114 S. Ct. 2309, 2322 (1994); Lucas v. South Carohna Coastal Council, 112 S. Ct. 2886, 2901 (1992); Nollan v. California Coastal Comm'n, 483 U.S. 825 (1987).

47. 502 U.S. $491,508-09$ (1992). 
ernment, involved not only the Court's enhanced protection of federahisin interests, ${ }^{48}$ but also presaged the Court's increasing sense that an aggressive reading of the Voting Rights Act may collide with equal protection principles. ${ }^{49}$

These three developinents-dictionaries, structural canons, and substantive canons-all illustrate that determinacy in adininistrative law is not directly related to greater deference to agencies. In fact, these trends demonstrate that the opposite might be true-developinent of craft norms that maximize judicial reputational utility appears to be related to less deference. What Shapiro and Levy are apparently searching for is not necessarily inore determinacy, but less judicial adventurism. However, these three developments deinonstrate that the Shapiro and Levy arguinent in favor of a Chevron-like regime of review will fail under their own construct. Shapiro and Levy posit that judges can inaximize reputation through craft excellence or maximize ideology while sacrificing craft. In either case, giving up ideological utility allows the judge to gain in reputational craft utility. But the broad deference position that was the basis for Chevron, as well as for the Shapiro and Levy reform, not only requires the judge to give up ideological utility but craft utility as well. A broad reading of Chevron tells the judge to defer if any ambiguity is found. Once the ambiguity is found, the craft task is over. In the typical admimistrative law case, it is probably true that finding ambiguity is easier than finding clarity. ${ }^{50}$ Chevron therefore gave judges less opportunity to

48. See id. at 510; Eskridge \& Frickey, supra note 15, at 619-25 (discussing federalism cases); see also United States v. Lopez, No. 93-1260, 1995 U.S. LEX1S 3039 (Apr. 26, 1995) (invalidating Gun-Free School Zones Act of 1990 as exceeding Congress's power under Commerce Clause); New York v. United States, 112 S. Ct. 2408, 2434 (1992) ("State governments are neither regional offices nor administrative agencies of the Federal Government.").

49. See Shaw v. Reno, 113 S. Ct. 2816, 2827 (1993) ("A reapportionment plan that includes in one district individuals who belong to the same race, but who are otherwise widely separated by geographical and political boundaries, . . . bears an uncounfortable resemblance to political apartheid."); Holder v. Hall, 114 S. Ct. 2581, 2591, 2592 (1994) (Thomas, J., concurring) (arguing for linited interpretation of the Voting Rights Act in vote dilution cases in order to discourage "racial 'balkaniz[ation]' of the Nation").

50. It may be that in certain cases it takes great craft skills to show ambiguity. But the incentives for the judge to demonstrate them appear absent. Assume that a judge is following the reading of Chevron that is in favor of broad deference. She decides that step two is triggered when an ambiguity level of $20 \%$ is found. Once the judge gets to that point-or just beyond it for insurance-she has no incentive to demonstrate skills to tease out more ambiguity. There is no payoff for doing so. But if a judge is going to set aside agency action under step one of Chevron, when there is a $70 \%$ level of confidence 
display those craft skills that earn them reputations for greatness. And, as noted above, they did so without getting any ideological utility in return. Craft in statutory interpretation is now being practiced by the Court-particularly in what appears to be a highly sophisticated way by some Justices-but usually in cases that the agency loses at step one of Chevron. The trade-off suggested by Shapiro and Levy was never a fair one for the judicial branch and therefore did not occur.

\section{CHEVRon AND AGENCY INCENTIVES, CONGRESS AS THE MECHANISM FOR COMMITMENT, AND THE NEED FOR MORE DETERMINATE CRAFT NORMS}

My third objection to the Shapiro and Levy proposal is that, like much of their paper, it looks only at judicial incentives and ignores the impact of Chevron or a Chevron-type review statute on both agencies and Congress. This narrow focus causes me to doubt the efficacy of and reasons for their proposal to amend the APA. Moreover, the substitution of legislative action for judicial crafting of standards of review is likely to prove futile, particularly if -as the Shapiro and Levy proposal implies-substantial leeway to develop and implement these new review standards is left to the courts.

Start first with agency incentives. What impact did Chevron have on agencies? I would suggest that the Chevron rule created bad incentives for the agencies by skewing agency resources in undesirable ways and shifting the power within the agency, as well as altering the power relationship between the agency and the agency's lawyer, the Department of Justice. It soon became clear that the overwhelming significance of Chevron focused upon the step-one analysis. Agencies would respond to this with a rational strategy. The significance of Chevron step one would lead the agency to devote more resources to the legalistic analysis that was at the core of Chevron step one than to policy expertise or political balancing. Chevron encouraged the agency to win at step one or at least to demonstrate sufficient ambiguity to make it a steptwo case. ${ }^{51}$ Therefore, scarce agency resources would be shifted

that the agency is wrong, the judge will have to demonstrate more skills to get to that point, and indeed may be driven to go past that point to justify substituting the judicial judgment for that of the agency.

51. A rational agency might always prefer to get past step one and win at step two. 
away from explanations that a court and the public might find more helpful. Even if the agency's resources are not scarce, the responsibility for explaining and justifying the agency's decision may reside even more exclusively in the hands of the agency's general counsel office. It is the agency lawyers who are expert at the legalistic expressions and justifications that Chevron step one accentuates, and therefore we should expect that the agency strategy will adjust accordingly. This may not be bad as long as policy and expertise are expressed in the explanation as well; however, time, space, and expertise limits may lead the agency lawyer to emphasize the law over the pohcy. ${ }^{52}$ Few would suggest that agencies are created to lend their expertise or accountability to doing strictly legal analysis.

But this is only part of the picture. Agencies must do battle not only with the courts to justify their decisions but with their lawyer as well-the Department of Justice. ${ }^{53}$ Since most agencies have no imdependent litigating authority, they have their views presented and defended in court only if the Department-usually through the Solicitor General-finds their views plausible. ${ }^{54}$ Again, insofar as Chevron step one assumed importance, the Department's role was only strengthened. It is the Department's lawyers-generalists to be sure, but speciahists in federal statutory and adinimistrative law-who are the true experts in doing the Chevron step-one analysis. Chevron then raised the potential for policy disputes witlim the executive branch to be controlled by the

If it wins at step one, it cannot later shift its position. This might not be the case when the agency is controlled by a strong President who wants to freeze his reading of the statute to bind successors and who therefore prefers to win the case at step one.

52. Consider the impact of the Supreme Court's highly textual analysis of a banking statute in Board of Governors of the Fed. Reserve Sys. v. Dimension Fin. Corp., 474 U.S. 361, 363 (1986) (discussing Bank Holding Co. Act of 1956 (12 U.S.C. $\$ \S 1841-1850)$ ). In the wake of Dimension, a series of administrative opinions by the federal banking agencies took on a textual character and often cited the case. See Decision of the Comptroller of the Currency on the Applications of American Security Bank, N.A., Washington, D.C. and Maryland National Bank, Baltimore Maryland, 1994 OCC Ltr. 9 (Feb. 4, 1994); Conımercial Paper Activities of Bankers Trust Co. of New York Do Not Constitute Underwriting Securities, Fed. Banking L. Rep. (CCH) 9 9 86,270, 90,823, 90,828 (June 4, 1985); Order Approving Applications to Engage in Limited Underwriting and Dealing in Certain Securities, 73 Fed. Res. Bd. Bull. 473, 475 (1987).

53. See Michael Herz, Comment, Textualism and Taboo: Interpretation and Deference for Justice Scalia, 12 CARDozo L. REv. 1663, 1681 (1991).

.54. See 28 U.S.C. \& 516 (1988) (reserving the power to conduct such litigation to the Departinent of Justice); 28 C.F.R. $\& 0.20$ (1994). 
Department, with disagreements expressed in Chevron step-one terms and the Chevron step-one threat always available for use by the Department (often at the behest of other agencies or OMB) to block agency initiatives. There is much to be said in favor of stronger presidential control over agency decisionmaking. ${ }^{55}$ It remains to be demonstrated that it was ideal or rational for this oversight to occur by the Department of Justice wielding the cudgel of Chevron step one.

These secondary effects of Chevron or a Chevron-like rule are not part of the Shapiro and Levy equation. Yet it surely seems odd to be proposing changes in judicial review of agency decisions without asking what mcentives are created for agencies under the proposal. Shapiro and Levy do propose significant and extensive amendments to the scope of review section of the Admimistrative Procedure Act, ${ }^{56}$ but agency behavior and institutional incentives are not targeted by their amendment. They claim that the suggested changes will restore the determinacy to scope of review that began with Chevron and State Farm $^{57}$ but did not endure. In making their suggestions, they do not directly enter into the debate about what standard of review is most consistent with separation of powers principles. They propose what they claim to be an "intermediate" view that preserves the judiciary's ability to enforce the rule of law, but without allowing courts to intrude into the sphere of legitimate agency policy choice..$^{58}$ In setting forth their amendments, they readily concede that no statutory standard can resolve every case or always constrain judicial choice. They do predict that more precise standards will channel judicial inquiry in a way that makes departures from craft norms more costly, and therefore will serve as a deterrent to judicial ideological adventurisin.

55. See Exec. Order No. 12,866, 3 C.F.R. 638 (1994), reprinted in 5 U.S.C.A. $\S 601$ (Supp. 1995); Exec. Order No. 12,291, 3 C.F.R. 127 (1982), reprinted in 5 U.S.C. \& 601 (1988); Lawrence Lessig \& Cass R. Sunstein, The President and the Administration, 94 Colum. L. Rev. 1, 85-86, 93-108 (1994); Christopher C. DeMuth \& Douglas H. Ginsburg, White House Review of Agency Rulemaking, 99 HARV. L. REV. 1075, 1080-82 (1986).

56. 5 U.S.C. \& 706 (1988); Shapiro \& Levy, supra note 5, at 1072.

57. Motor Vehicles Mfrs. Ass'n v. State Farm Mut. Auto. Ins. Co., 463 U.S. 29 (1983).

58. Shapiro \& Levy, supra note 5, at 1070-71. 
Their proposal is comprehensive, yet their narrow focus on restoring a Chevron-type review standard leaves me pessimistic that the reforn will occur. Moreover, by proposing general and vague standards for review, they have ignored various craft norms that might be better in changing agency and judicial incentives in ways that Shapiro and Levy may find desirable. Shapiro and Levy may be correct that the Justices were quite unwilling to give up their power post-Chevron. Yet the prospects for legislative relief remain uncertain even if the legislature rather than the Court acts as the third-party enforcer to secure a commitment to a new set of more determinate craft norins. The scope of review standard outlined by Shapiro and Levy for guiding review of agency interpretations of statutory law may be as subjective and open-ended as those articulated in Chevron. Moreover, we saw that the determinacy of Chevron came not so much from the two-part test as the general signal sent by the Court. Thus, the proposed APA amendments may suffer from the same infirmities that we saw in Chevron: the actual test is unlikely to provide serious constraint and the general exhortation to defer unless the law is clear will leave judges with substantial discretion. In this respect, the judiciary will again prove to be pivotal in implementing, defining, and morntoring the new statute. And the same problems of discerning real defections and auditing will arise.

The anbitious but (I fear) largely hortatory effort made by Shapiro and Levy fails to take account of the broad variation in statutory questions and contexts that arise across the many different types of administrative agencies. Statutory questions in administrative law are unlikely to be captured under one simple formulation. This all suggests that to seriously imject the idea of craft norms into administrative law doctrine requires formulation beyond the simple and general Chevron two-step, whether it be found in caselaw or statutory law. Statutory cases are too idiosyncratic or umque to achieve consistency in generally stated craft norms across a wide spectrum of cases. The process of comparing clarity or unmistakable intent from case to case will produce few true examples in which craft can be readily observed. Indeed, post-Chevron law quickly disintegrated into a sequence of charges and countercharges about who did or did not defer in the last case. The solution must be to seek out craft norms that transcend the particular statutory analysis, that can then be applied across all 
agencies despite the diversity of text, legislative history, or statutory purposes.

Here I would urge them to look both at pre- and post-Chevron law. As others have observed, the pre-Chevron approach was contextual and practical, focusing on a number of factors and not simply on the narrow Chevron step-one imquiry. ${ }^{59}$ The whole of the agency decisionmaking process and its placement in statutory law was critical in deciding the deference question. These factors mcluded the consistency of the agency's position over time, the amount of time that the policy has been in place, the form of the agency action, and whether the agencies involved have all spoken with a single voice on the issue. ${ }^{60}$ Under both the traditional ${ }^{61}$ as well as the more modern defense ${ }^{62}$ of this approach, these factors were deemed relevant to the ultimate persuasiveness of the agency's decision. The advantage of these factors for Shapiro and. Levy's proposed reform is that they provide clearer craft norms that transcend the individual statutory setting. There certainly will be instances when the courts do not consider these factors or apply them inconsistently. But the more precise and portable character of these factors across statutes and agencies assures that the reputational sanctions that Shapiro and Levy seek will in fact be felt by those who do not play the game by the rules. Judges who ignore them will be seen as ideological maximizers whose reputations should decline accordingly.

Another major advantage of this approach is that it has the possibility of producing a relatively stable judicial consensus across the spectrum of ideological judges. With different ideologies, judges will obviously disagree im individual cases whether the agency should prevail or not. But the differing judges may agree that the review standards should be created $\mathrm{m}$ a way to promote fair, unbiased, rational, and politically accountable decisionmaking. Some of the contextual factors outlined above are directly related to these more umiversal goals of admimistrative government. Con-

59. See Merrill, supra note 28, at 352 (contrasting Chevron with "the older pragmatic tradition that emphasized a variety of contextual factors"); Merrill, supra note 4, at 972 (calling pre-Chevron test "pragmatic and contextual").

60. See Merrill, supra note 4, at 1016-22.

61. See Skidmore v. Swift \& Co., 323 U.S. 134, 140 (1944).

62. See Mayburg v. Secretary of Health \& Human Servs., 740 F.2d 100, 105-07 (1st Cir. 1984) (Breyer, J.); Merrill, supra note 4, at 1016-22; see also Sunstein, supra note 15, at 443-46 (arguing against a general rule of deference to agency interpretations). 
sider the problem of a conflict in views among administrative agencies. A judge believing that political accountability is a bedrock principle of scope of review law will be keenly interested in whether the agencies are in conflict. The problem most frequently arises when an imdependent agency, not subject to direct Presidential control, ${ }^{63}$ disagrees with the views of a purely executive agency. In the 1980s, the pohitically independent Federal Reserve Board opposed the deregulatory measures of the more politically accountable Department of the Treasury and Comptroller of the Currency. The Board's actions to halt deregulation were consistently invalidated by the courts. ${ }^{64}$ No deference to the Board was granted because of the schism among the banking agencies. ${ }^{65}$ This is desirable for judges who want politically accountable agencies. The unaccountable Board is due less deference when the President and his subordimates set forth a different policy view. The conflict annong agencies will also be relevant for those judges who seek to further deliberation and rationality in agency decisionmaking. It may suggest haste by the Board in taking action or an absence of persuasiveness to its rationale. ${ }^{66}$

Acting in the shadow of these contextual factors is not without cost to the agency. Under the view set forth by Shapiro and Levy, there would be a freeing up of agency resources since the apparent decline in scrutiny would lessen the burdens on agency decisionmaking. But these factors are quite different from the unpredictable and vacillating judicial attitudes of either strict or deferential review. These contextual factors tend to place the agency in the position of controlling the amount of deference it receives. They are designed not simply to operate as ex post justifications for a result but to alter the incentives for agency action. ${ }^{67}$ An agency that is aware ex ante that a conflict in agency

63. See Humphrey's Executor v. United States, 295 U.S. 602, 624-26 (1935) (describing independence of Federal Trade Commission froin executive control); see also id. at 610-11 (saine, in oral arguinent of William J. Donovan).

64. See Board of Governors v. Dimension Fin. Corp., 474 U.S. 361, 374 (1986); Citicorp v. Board of Governors, 936 F.2d 66, 73 (2d Cir. 1991), cert. denied, 502 U.S. 1031 (1992); Synovus Fim. Corp. v. Board of Governors, 952 F.2d 426, 436 (D.C. Cir. 1991); cf. FAIC Sec., Inc. v. Umited States, 768 F.2d 352, 361-62 (D.C. Cir. 1985) (invalidating FDIC regulation opposed by the Department of Treasury and Antitrust Division of the Department of Justice).

65. See Citicorp v. Board of Governors, 936 F.2d 66, 75-76 (2d Cir. 1991).

66. For a good example of this view, see Judge Newman's discussion in Citicorp, id. at 75 .

67. See Merrill, supra note 4, at 1029 (arguing that the Chevron focus on judicial 
views or a shift in agency position will tend to lower the amount of deference can plan accordingly and make up for the loss by articulating its position more carefully or with more support from practical experience. As noted above, Chevron created no such incentives and indeed skewed them in particularly perverse ways. In suggesting that so much was at stake in step one of the analysis, the message sent to agencies was to make sure that they devote their time to explaining why either they win at step one, or why the statute is ambiguous and warrants only the minimal scrutiny under step two. With limited resources and staff, the agencies were forced not to do what they are supposed to do best-apply their expertise or resolve political or policy disagreements rationally-but to channel these scarce resources into legalistic formulations.

Therefore, Shapiro and Levy would be better off to insert into their reform package the factors that can indeed be identified as craft norms. ${ }^{68}$ By doing so, they will at least allow for the enforcement of the reputational sanctions that simply could not be administered under Chevron and likely would prove to be ephemeral under their proposal as well. Moreover, in making the agency "earn" deference, the traditional factors create the proper incentives for agency action as well as halting the diversion of agency resources froin explaining and justifying expert policy judgments to legahistic explanations. In this last respect, this incentive-based

\footnotetext{
behavior creates no incentives for agencies). This incentive theory of earning deference can be seen in a variety of contexts. One is that in which the Court alters its level of deference and the aggressiveness of its Chevron step-one posture depending on how the agency expressed its views. See Massachusetts v. FDIC, 47 F.3d 456, 459 (1st Cir. 1995) (noting that choice of whether to adopt formal adjudication up to agency but further stating that doing so would consume agency resources and earn agency greater deference); New York City Einployees' Retireinent Sys. v. SEC, 45 F.3d 7, 14 (2d Cir. 1995) (agency may adopt interpretive rules without notice and comment or even inore informal "no-action" letters but these are entitled to less deference than formally adopted legislative rules); John Hancock Mut. Life Ins. Co. v. Harris Trust \& Sav. Bank, 114 S. Ct. 517, 531 (1993) (leaving open whether agency position adopted in brief was entitled to deference, but finding such a position first articulated in the Solicitor General's amicus brief unpersuasive); Callejo v. Resolution Trust Corp., 17 F.3d 1497, 1499 (D.C. Cir. 1994) (tying standard of review of agency decision to whether agency proceeded by informal adjudication or formal adjudication controlled by promulgated regulations). In a recent decision, the Court has also suggested that the agency's views are due less weight when the agency has sought to preclude judicial review of its decisions. See Brown v. Gardner, 115 S. Ct. 552, 557 (1994).

68. For an earher effort to do so, see generally Ronald M. Levin, Scope-of-Review Doctrine Restated: An Administrative Law Section Report, 38 ADMIN. L. REV. 239 (1986).
} 
approach at least allows the agency to play some role in determining the reception it will receive when judicial review is sought, and makes the deference analysis less likely to appear as conclusory judicial whim. Given that it is the fear of the latter that dominates not only the Shapiro and Levy paper but the more general discourse on Chevron and scope of review, the former may be viewed at least as a small step forward in working out the relationship between courts and agencies. 